\title{
Susceptibility of kiwifruit shelter species to two armoured scale insects
}

\author{
N.A. Mauchline ${ }^{1}$, M.G. Hill ${ }^{1}$, K.A. Stannard ${ }^{1}$ and Q.G. Zhuang ${ }^{2}$ \\ ${ }^{1}$ The New Zealand Institute for Plant E Food Research Limited, 412 No 1 Road, RD2, \\ Te Puke, 3182, New Zealand \\ 'Sichuan Academy of Natural Resource Sciences, 24 South $2^{\text {nd }}$ section, Yihuan Road, \\ Chengdu 610015, Sichuan, China \\ Corresponding author: Garry.Hill@plantandfood.co.nz
}

\begin{abstract}
The relative susceptibility to greedy and latania scale of 21 tree species used as kiwifruit shelter was determined using laboratory and shade house bioassays. The bioassays confirmed the general susceptibility of most of the willow and poplar selections, but showed that some selections had good levels of resistance, measured by scale insect survival and growth. For some shelter species, resistance to the two armoured scale species differed. The most resistant of the commonly used shelter species were Bambusa oldhami, Pinus radiata and Cryptomeria japonica. Other less commonly used species such as Pittosporum spp. also showed good resistance. Using these resistant species as shelter in a kiwifruit orchard will minimise the risk of the shelter becoming a reservoir for either species of armoured scale.
\end{abstract}

Keywords kiwifruit, armoured scale, shelter, host plant resistance.

\section{INTRODUCTION}

The armoured scale species Hemiberlesia rapax Comstock (greedy scale) and H. lataniae Signoret (latania scale) are important pests of kiwifruit (Hill et al. 2009). Prior field research has shown that several shelter species can harbour scale insects (Blank et al. 1987; Blank et al. 1990; Jamieson et al. 2002). However, there have been no comparative studies of the susceptibility of shelter species to the two armoured scale insects.

Shelter is necessary around kiwifruit blocks to reduce wind damage. Poplar and willow have been widely used for shelter but are being superseded by other species. Cryptomeria japonica is now probably the most commonly planted shelter species in kiwifruit orchards, functioning primarily to block the wind. Also very common are Casuarina species and Crow's nest poplar, which serve as wind filters, and Alnus species, which provide a source of nitrogen in addition to wind protection.

A bioassay that measures the survival and growth of armoured scale insects on cut canes developed to study the resistance of kiwifruit vines to armoured scales (Hill et al. 2010), was adapted to test the susceptibility of shelter species to such insects. The aims of this study were to test the efficacy of this bioassay in assessing shelter species, and to determine the comparative susceptibility of several common kiwifruit shelter species to both $H$. rapax and H. lataniae, 
using bioassays to measure armoured scale insect settlement, survival and growth.

\section{MATERIALS AND METHODS \\ Laboratory bioassay}

Unsprayed plants of 21 kiwifruit shelter species (Table 1) were obtained from shelter belts on several orchards and from two local nurseries in August and September 2009. The material was held in a coolstore at $0^{\circ} \mathrm{C}$ until the experiment was set up in December 2009. One-year-old cuttings, $40 \mathrm{~cm}$ long and free of scales, were removed from the plants, buds and shoots were removed, and all exposed cut surfaces, except the bottom of the cutting, were sealed with grafting wax. A length of wool was wrapped around the cutting to provide a shelter under which scale insect crawlers could settle, and the end of the cutting was placed in a pottle of water inside a large plastic bin. One hundred crawlers of either $H$. rapax or $H$. lataniae from single species laboratory cultures, were placed onto each cutting and the cuttings were held in a constant environment room $\left(20^{\circ} \mathrm{C} \pm 2^{\circ} \mathrm{C}\right.$, $70 \% \mathrm{RH}$ and 16:8 h light:dark). Five replicate cuttings were used for testing $H$. lataniae on each shelter species, but only one cutting was used per shelter species for $H$. rapax because the laboratory culture was too small to produce more crawlers. Cuttings with $H$. rapax or $H$. lataniae were held in separate rooms, along with their respective cultures, to avoid contamination. Seven to 10 days after crawler settlement, the wool was removed from the cuttings and the number of settled first instars of each species was counted. The cuttings were held for a further 9 weeks. Water in the pottles was topped up weekly and re-growth of side shoots on the cuttings was removed. At the end of the experiment each of the remaining scale insects on each cutting was assessed visually as alive or dead and scored for size using a template drawn on a clear plastic sheet that allowed the area of the scale cap to be estimated in units of $0.2 \mathrm{~mm}^{2}$. Further details are in Hill et al. (2010).

Differences between the shelter species in the number of settled $H$. lataniae per cutting 1 week after being infested, and the numbers of live $H$. lataniae and those reaching full adult size $\left(>1.2 \mathrm{~mm}^{2}\right.$ cap area (Hill et al. 2011a)) per cutting at the end of the experiment were tested using one way ANOVA (Minitab 16), with log transformation where necessary. The standards were not included in the analysis, nor were shelter species that had zero settlement or survival. Correlations between the three resistance measures were calculated using Spearman's ranking method.

\section{Semi-field bioassay}

The bioassay carried out in 2009-10 was repeated a year later using 1.5-2 $\mathrm{m}$ tall unsprayed potted plants of seven shelter species chosen as representatives of the common shelter types (Table 2). All plants were obtained from a local nursery, re-potted into 18-litre plastic bags on 18-19 August 2010 and maintained outdoors in a plant nursery at the Plant \& Food Research Te Puke Research Centre. The commercial kiwifruit cultivars Actinidia deliciosa 'Hayward' and A. chinensis 'Hort16A' were included as standards. Using the same methods as for the laboratory bioassay, 100 crawlers of each species were settled onto two sites on each of five plants of each shelter or kiwifruit variety between 10 and 16 November 2010. The plants were held in a shade house $(50 \%$ shading). On 25-26 November 2010, the wool was removed and settled first instar scale insects counted. Approximately 11 weeks after crawler settlement, on 7-11 February 2011, the number of live scale insects was counted on each plant and the area of the cap of each scale insect measured as described above. Differences between the means were assessed using the same methods described above for the laboratory bioassay and differences between individual means were tested using Tukey's HSD test (family $\alpha=0.05$ ).

\section{RESULTS}

\section{Laboratory bioassay}

The $H$. rapax rearing room malfunctioned during the experiment and as a result none of the canes survived sufficiently long to allow the insects to mature. Thus, only initial crawler settlement data were obtained. The results for both insect species (Table 1) showed differences in the initial crawler settlement on the plants, which was highly 
significant for $H$. lataniae $(\mathrm{P}<0.001)$. Differences in H. lataniae survival and growth (last 2 columns in Table 1) on the tree species were very marked $(\mathrm{P}<0.001)$. One species, bamboo, was entirely unsuitable for crawler settlement. Seven other tree species could not support scale insect survival to the end of the experiment and nine tree species failed to support scale growth to adult size $\left(1.2 \mathrm{~mm}^{2}\right.$ cap area). The most susceptible species were four types of willow and two of poplar (Table 1), although one willow and one poplar selection ( $S$. matsudana $\times$ S. alba 'Moutere' and $P$. deltoides $x$ P. nigra 'Tasman') did not support growth and survival of latania scale (Table 1).

Cupressus leylandii and A. cordata were also quite susceptible and able to support growth of latania scale to adulthood in small numbers and A. glutinosa, C. lawsoniana and the two Casuarina species were also able to support $H$. lataniae growth to adulthood, but survival was very low in these species.

There was a strong rank correlation between survival and insect size $\left(r_{s}=0.86, P<0.001\right)$ and much weaker but still significant correlations between log crawler settlement number and each of the other two measures (scale survival: $\mathrm{r}_{\mathrm{s}}=0.36$.; $\mathrm{P}<0.01 ;$ scale size: $\mathrm{r}_{\mathrm{s}}=0.32 ; \mathrm{P}=0.01$ ).

\section{Semi-field bioassay}

The ANOVA results for crawler settlement and numbers surviving to the end of the experiment showed a significant interaction between shelter

Table 1 Armoured scale insect settlement after 10 days, and survival and growth after 10 weeks on cuttings of 21 shelter types held at $20^{\circ} \mathrm{C}$ and $70 \% \mathrm{RH}$. Values are mean numbers surviving out of 100 crawlers ( $H$. lataniae, $\mathrm{n}=5$ cuttings; $H$. rapax, $\mathrm{n}=1$ cuttings). Means with the same letter in the same column are not significantly different (Tukey's HSD, $\alpha=0.05$ ). Results for kiwifruit cultivars are included for comparison.

\begin{tabular}{|c|c|c|c|c|}
\hline \multirow[b]{2}{*}{ Shelter species } & \multicolumn{2}{|c|}{ At settlement } & \multicolumn{2}{|c|}{ At end of bioassay } \\
\hline & H. rapax & H. lataniae & Live scale & Scale $>1.2 \mathrm{~mm}^{2}$ \\
\hline Salix matsudana $x$ S. alba 1002 'Aokautere' & 36 & $68.4 \mathrm{ab}$ & $46.0 \mathrm{ab}$ & $41.2 \mathrm{a}$ \\
\hline 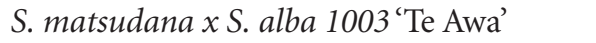 & 46 & $79.8 \mathrm{ab}$ & $43.4 \mathrm{ab}$ & $38.6 \mathrm{ab}$ \\
\hline Populus deltoides $x$ P. nigra 'Crow's nest' & 27 & $57 \mathrm{abc}$ & $47.2 \mathrm{a}$ & $36.2 \mathrm{ab}$ \\
\hline Populus nigra'Italica' & 36 & $75.4 \mathrm{ab}$ & $39.4 \mathrm{abc}$ & $33.8 \mathrm{abc}$ \\
\hline Salix matsudana x S. alba 1040'Tangoio’ & 50 & $71 \mathrm{ab}$ & $39.4 \mathrm{abc}$ & $30.8 \mathrm{abc}$ \\
\hline Salix matsudana 'Matsudana willow' & 41 & $76.6 \mathrm{ab}$ & 22.0 abcde & $20.2 \mathrm{abcd}$ \\
\hline Cupressus leylandii & 28 & 50 abcd & 16.2 bcde & $14.4 \mathrm{bcd}$ \\
\hline Alnus cordata & 29 & $68.8 \mathrm{ab}$ & 30.8 abcd & $10.0 \mathrm{~cd}$ \\
\hline Cupressus lawsoniana & 26 & 46 bcd & 8.4 de & $4.6 \mathrm{~d}$ \\
\hline Casuarina glauca & 29 & $58.5 \mathrm{abc}$ & $6.6 \mathrm{de}$ & $2.5 \mathrm{~d}$ \\
\hline Casuarina cunninghamii & 39 & 88 a & 10.4 cde & $1.4 \mathrm{~d}$ \\
\hline Alnus glutinosa & 23 & $54.2 \mathrm{abc}$ & $7.0 \mathrm{de}$ & $0.2 \mathrm{~d}$ \\
\hline Crytomeria japonica & 6 & $12.4 \mathrm{~d}$ & $1.17 \mathrm{e}$ & 0 \\
\hline Eucalyptus globulus & 6 & $56.2 \mathrm{ac}$ & 0 & 0 \\
\hline Pinus radiate & 7 & $19.2 \mathrm{~cd}$ & 0 & 0 \\
\hline Pittosporum crassifolium & 23 & $63.0 \mathrm{ab}$ & 0 & 0 \\
\hline Pittosporum eugenioides & 15 & $48.8 \mathrm{abcd}$ & 0 & 0 \\
\hline Pittosporum tenuifolium & 18 & $82.4 \mathrm{ab}$ & 0 & 0 \\
\hline Populus deltoides $x$ P. nigra 'Tasman' & 40 & $60.0 \mathrm{ab}$ & 0 & 0 \\
\hline Salix matsudana $x$ S. alba 1184 'Moutere' & 32 & $73.4 \mathrm{ab}$ & 0 & 0 \\
\hline Bambusa oldhami & 0 & 0 & 0 & 0 \\
\hline Actinidia deliciosa 'Hayward' & 35 & 69.2 & 58.6 & 56.8 \\
\hline Actinidia chinensis 'Hort16A' & 24 & 66.4 & 0 & 0 \\
\hline
\end{tabular}


species and scale insect species $(\mathrm{P}<0.001)$ (Table 2 ). Crawler settlement ranged from 0 to $70 \%$, but showed less variation between shelter species than insect survival. Settlement of $H$. lataniae was significantly greater than $H$. rapax on C. cunninghamii and S. matsudana. Crytomeria japonica, C. leylandii and $P$. tenuifolium failed to support survival of either species to the end of the experiment. Survival of $H$. lataniae (17\%) was significantly greater than $H$. $\operatorname{rapax}(0.6 \%)$ on S. matsudana (Table 2). The ANOVA for log numbers $>1.2 \mathrm{~mm}^{2}$ showed a significant effect for plant species (Table 3; $\mathrm{P}=0.002$ ) but not for scale species $(\mathrm{P}=0.24)$ or the interaction $(\mathrm{P}=0.289)$. Overall, the willow and poplar species were the most susceptible.

There was a strong correlation between the log number of live scale at the end of the experiment and the log of scale numbers $>1.2 \mathrm{~mm}^{2}\left(\mathrm{r}_{\mathrm{s}}=0.86\right.$; $\mathrm{P}<0.001 ; \mathrm{n}=46$ ), and weaker but still significant correlations between $\log$ crawler settlement number and each of the other two measures (scale survival: $\mathrm{r}_{\mathrm{s}}=0.68 ; \mathrm{P}<0.001$; scale size: $\left.\mathrm{r}_{\mathrm{s}}=0.63 ; \mathrm{P}<0.001\right)$.

Table 2 Mean scale insect (crawler) settlement per plant and mean numbers of live scale per cane after 11 weeks of potted plant bioassays at ambient in a shade house, $n=200$ crawlers. Within each measure, mean values with the same letter are not significantly different (Tukey's HSD, $\alpha=0.05$ ). Results for kiwifruit cultivars are included for comparison.

\begin{tabular}{lcccccc}
\hline & \multicolumn{2}{c}{ Crawler settlement } & & \multicolumn{3}{c}{ Live scale } \\
\cline { 2 - 3 } \cline { 6 - 7 } Shelter species & H. lataniae & H. rapax & & & H. lataniae & H. rapax \\
\hline Salix matsudana 'Matsudana willow' & $82.4 \mathrm{ab}$ & $13.8 \mathrm{~cd}$ & & $34.8 \mathrm{a}$ & $1.2 \mathrm{~b}$ \\
Populus deltoides x P. nigra 'Crow's nest' & $140.2 \mathrm{a}$ & $93.4 \mathrm{a}$ & & $28.8 \mathrm{a}$ & $25.4 \mathrm{a}$ \\
Alnus glutinosa & $58.3 \mathrm{abc}$ & $85.0 \mathrm{ab}$ & & $15.8 \mathrm{ab}$ & $21.0 \mathrm{a}$ \\
Casuarina cunninghamii & $43.0 \mathrm{abc}$ & $14.2 \mathrm{~d}$ & & $16.8 \mathrm{ab}$ & $3.8 \mathrm{~b}$ \\
Cryptomeria japonica & $17.0 \mathrm{bcd}$ & $54.5 \mathrm{abc}$ & & 0.0 & \\
Pittosporum tenuifolium & 0.0 & $19.8 \mathrm{abcd}$ & & 0.0 & 0.0 \\
Cupressus leylandii & 0.0 & $41.8 \mathrm{abc}$ & & 0.0 & 0.0 \\
'Hayward' & 124.8 & 16.0 & & 25.8 & 4.0 \\
'Hort16A' & 124.6 & 42.5 & & 0.0 & 3.8 \\
\hline
\end{tabular}

Table 3 Mean number of large armoured scale insects $\left(>1.2 \mathrm{~mm}^{2}\right)$ per cane at the end of a semi-field bioassay. Results for both scale insect species combined, $n=200$. Results for kiwifruit cultivars are included for comparison.

\begin{tabular}{lc}
\hline Shelter species & Number of scale insects $>1.2 \mathrm{~mm}^{2}$ \\
\hline Populus deltoides $x$ P. nigra 'Crow's nest' & $14.4 \mathrm{a}$ \\
Salix matsudana 'Matsudana willow' & $7.6 \mathrm{ab}$ \\
Casuarina cunninghamii & $6.8 \mathrm{ab}$ \\
Alnus glutinosa & $4.8 \mathrm{~b}$ \\
Cryptomeria japonica & $0.4 \mathrm{~b}$ \\
Pittosporum tenuifolium & 0.0 \\
Cupressus leylandii & 0.0 \\
'Hayward' latania & 2.6 \\
'Hayward' greedy & 1.0 \\
'Hort16A' latania & 0.0 \\
'Hort16A' greedy & 3.5 \\
\hline
\end{tabular}




\section{DISCUSSION}

A bioassay developed for assessing resistance of kiwifruit vines to armoured scale insects was successfully adapted to assess the relative susceptibility of a range of shelter species to the two main armoured scale species attacking kiwifruit in New Zealand. While there were differences in the responses of the two scale insect species to the same shelter species, notably on S. matsudana (Table 2), the results confirm previous studies showing that the commonly used poplar and willow selections are susceptible hosts of kiwifruit armoured scale insect pests. However, the finding that some willow and poplar selections (S. matsudana $x$ S. alba 'Moutere' and P. deltoids $x$ P. nigra 'Tasman') did not support growth and survival of latania scale in the laboratory bioassay (Table 1) suggests that, with further confirmatory testing, they could be used as kiwifruit shelter. These selections are not commonly used in kiwifruit orchards at present. Of the more commonly used shelter species, bamboo (B. oldhami), Japanese cedar (C. japonica), and Monterey pine (P. radiata) appear to be the best choice for armoured scale resistant shelter. Pittosporum species also appear to be suitable but are less commonly used.

The advantage of a bioassay method for assessing resistance is that it allows a quick, cheap and controlled comparative assessment of resistance between shelter species. It avoids issues with resistance measures based only on field observations where prior insecticide treatments can mask shelter susceptibility (Jamieson et al. 2002). However, bioassays measure only the direct physical insect-plant interaction. Ecological factors will also influence pest dynamics and hence overall plant susceptibility. For example, the invasion pressure from armoured scale insect populations in bush adjacent to kiwifruit orchards can be influenced by parasitism (Blank et al. 1987; Blank et al. 1995). The unrooted cutting laboratory bioassay used here has been extensively tested on kiwifruit to ensure that it can mimic responses of whole plants to armoured scale insect attack (Hill et al. 2007; Hill et al. 2010) but has not previously been tested on other plant types. The general agreement between the results for the laboratory cutting and potted plant bioassays and with previous field studies (Jamieson et al. 2002) suggests that the results from the cutting bioassay are reasonably reliable, although the assay may not work equally well for all plant types. Nothing is known about the mechanisms of the variation in scale insect resistance or susceptibility in these tree species. However, latania scale resistance in the variety 'Hort16A' arises from a major gene-based hypersensitivity leading to a localised physical response in tissues surrounding the insect that causes death (Hill et al. 2011b).

\section{ACKNOWLEDGEMENTS}

Jill Phare and Larissa Halcombe provided technical assistance. Graham Walker and Peter Lo made very helpful comments on an earlier draft and Patrick Connolly provided statistical advice. We acknowledge financial support from the Ministry of Science and Innovation (Contract C06X0810) and the Plant \& Food Research Capability Fund.

\section{REFERENCES}

Blank RH, Olson MH, Bell DS 1987. Invasion of greedy scale crawlers (Hemiberlesia rapax) onto kiwifruit from taraire trees. New Zealand Entomologist 10: 127-130.

Blank RH, Olson MH, Lo PL 1990. Armoured scale (Hemiptera: Diaspididae) aerial invasion into kiwifruit orchards from adjacent host plants. New Zealand Journal of Crop and Horticultural Science 18: 81-87.

Blank RH, Gill GSC, Olson MH 1995. Seasonal abundance of greedy scale (Homoptera: Diaspididae) and associated parasitoids on taraire (Beilschmiedia tarairi). Journal of Economic Entomology 88: 1634-1640.

Hill MG, Henderson RC, Mauchline NA 2011a. Diaspidid (Hemiptera:Coccoidea) size plasticity as an adaptive life history trait. European Journal of Entomology 108: 153159.

Hill MG, Mauchline N, Cheng CH, Connolly PG 2007. Measuring the resistance of Actinidia chinensis to armoured scale insects. Acta Horticulturae 753: 685-692. 
Hill MG, Mauchline NA, Hall AJ, Stannard KA 2009. Life table parameters for two armoured scale insect species on resistant and susceptible kiwifruit (Actinidia sp.) germplasm. New Zealand Journal of Crop and Horticultural Science 37 (4): 335-343.

Hill MG, Mauchline N, Connolly PG, Maher B 2010. Measuring resistance to armoured scale insects in kiwifruit (Actinidia) germplasm. New Zealand Journal of Crop and Horticultural Science 38: 69-85
Hill MG, Mauchline N, Jones MK, Sutherland PW 2011b. The response of resistant kiwifruit (Actinidia chinensis) to armoured scale insect (Diaspididae) feeding. Arthropod - Plant Interactions 5: 149-161.

Jamieson L, Dobson S, Cave J, Stevens PS 2002. A survey of armoured scale insects on kiwifruit shelter. New Zealand Plant Protection 55: 354-360. 